\title{
The Antioxidant Status and Biochemical Parameters in Kid Goats Naturally Infected with Peste Des Petits Ruminants Virus
}

\author{
Ersoy Baydar', Abdurrauf Yuce ${ }^{2}$, Metin Gurcay ${ }^{3} \&$ Omer Kizil ${ }^{4}$
}

\begin{abstract}
Background: Peste des petits ruminants (PPR) is an acute and highly contagious viral disease of small ruminants. The disease is high economical importance because of the high mortality rate. Oxidative stress is an active field of research in small ruminant medicine and has been implicated in numerous disease processes including sepsis, mastitis, acidosis, enteritis, pneumonia, respiratory, and joint diseases. Compared to human medicine, only a limited number of conditions have been investigated in regard to the effects of oxidative stress in small ruminants. The aim of this study was to determined and compared the oxidative status and some biochemical parameters in kid goats with PPR.

Materials, Methods \& Results: The study was performed on 15 healthy hair of kid goats (control group) and 15 kids naturally infected with Peste des Petits Ruminants (PPR). Competitive enzyme linked immunosorbent assay (C-ELISA) was used for serological detection of PPRV specific antibodies, and a reverse transcription polymerase chain reaction (RT-PCR) was performed for the detection of PPR virus. Concentrations of plasma biochemical parameters were analysed by a clinical chemistry analyser, and blood biochemical indices determined, including total protein, albumin, alkaline phosphatase (ALP), aspartate amino transferase (AST), $\gamma$ - glutamyl transferase (GGT), lactate dehydrogenase (LDH), glucose, very low density lipoprotein (VLDL), low density lipoprotein (LDL), high density lipoprotein (HDL). The plasma CAT activity, plasma GSHPx activity and plasma lipid peroxidation level was measured according to the specific methods. Besides, vitamin $\mathrm{C}$ values were colorimetrically determined using a phosphotungustic method acid method and vitamin $\mathrm{E}$ values were determined spectrophotometrically method. Plasma MDA concentrations were markedly increased in the group of kid goats with PPR $(P<0.001)$ whereas GSHPx $(P<0.01)$, and CAT $(P<0.01)$ activities were significantly depressed as well as concentrations of vitamins $\mathrm{E}(P<0.05)$ and vitamin $\mathrm{C}(P<0.001)$. Significant differences between groups were showed relative to plasma total protein $(P<0.05)$, albumin $(P<0.05)$, ALP $(P<0.05)$, AST $(P<0.01)$, GGT $(P<0.05)$, LDH $(P<0.05)$, glucose $(P<0.001)$, VLDL $(P<0.05)$, LDL $(P<0.01)$, and HDL $(P<0.05)$

Discussion: The clinical and postmortem findings of PPRV infection may be sufficient for the diagnosis in the endemic areas, yet labaratory confirmation is essential for definitive diagnosis because of the clinical similarity of PPR to rinderpest. In this study used both C-ELISA and RT-PCR in the diagnosis of suspected disease. The decrease level of VLDL, LDL, and HDL in the kids with PPR were consistent findings with liver damage, and the cause of decrease could be inadequate synthesis of cholesterol that main structure of lipoproteins due to liver dysfunction. Plasma MDA concentrations were found to be increased in the kid goats with PPR compared to the control group, while decreases of GSHPx and CAT activities were observed. Because of GSHPx and CAT are involved in the conversion of radicals into less effective metabolites, these changes coupled to the increase of MDA concentrations, suggest that an excessive ROS production occurred during PPR infection. This study has highlighted the occurrence of an oxidative stress with important differences in antioxidant status as reflected by assessment of some enzymatic and non-enzymatic antioxidants in kids infected by PPRV. In conclusion, this study has highlighted the occurrence of an oxidative stress with important differences in antioxidant status as reflected by assessment of some enzymatic and non-enzymatic antioxidants in kids infected by PPRV. Furthermore, the liver was effected by PPRV infection.
\end{abstract}

Keywords: antioxidant, biochemistry, kids, goats, liver, PPRV. 
E. Baydar, A. Yuce, M. Gurcay \& O. Kizil. 2018. The Antioxidant Status and Biochemical Parameters in Kid Goats Naturally Infected

\section{INTRODUCTION}

PPRV is a morbillivirus and is related to rinderpest virus, canine distemper virus, and the human measles virus $[13,41]$. Peste des petits ruminants (PPR) is an acute and highly contagious viral disease of small ruminants [12,32]. The PPRV spreads close contact by aerosol route between infected and susceptible animals $[3,41]$. The infection is characterized by fever, erosive, necrotic stomatitis, diarrhea, anorexia, prulent ocular and nasal discharges, and respiratory distress $[41,46]$. Morbidity and mortality could be very high especially in non-vaccinated young animals than in adults $[13,15,26]$. The PPRV infection more severe in goats as compared to sheep $[12,33,43]$. The disease is high economical importance because of the high mortality rate and restriction on livestock trading $[1,33]$.

A free radical can be described as any atom or a group of atoms or molecules in which there is at least one unpaired electron in the outermost shell [38]. Usually, organism has sufficient antioxidant reserves to cope with the production of free radicals $[7,41]$ but the imbalance between the production of ROS (Radical Oxygen Species) and the availability of antioxidant molecules may result in oxidative stress $[6,21,40]$. The components of the antioxidant system have been classified as preventive and chain breaking antioxidants. Glutathione peroxidase (GSHPx) and catalase (CAT) are anti-oxidant enzymes [14,29,40]. The chain-breaking antioxidants act after initiation of a chain reaction. This class of antioxidants includes reduced lipid soluble vitamin E [41], and water soluble ascorbate [38]. Whenever equilibrium between ROS and antioxidants is broken, progressive oxidation of other biological substrates (such as lipids, DNA and proteins) occurs, establishing an oxidative stress status that may impair health both directly and indirectly whenever equilibrium between ROS and antioxidants is broken, progressive oxidation of other biological substrates (such as lipids, DNA and proteins) occurs, establishing an oxidative stress status that may impair health both directly and indirectly $[14,40]$. Direct effects include peroxidation damage to important lipids and macromolecules. Indirect changes include effects on cellular membranes and components, modifying metabolic pathways and resulting in altered physiology [7].

The aim of this study was to determined and compared the oxidative status and some biochemical parameters between kid goats with PPR and healthy controls on the basis of plasma lipid peroxidation intensity (MDA), antioxidant enzyme activities, chain breaking antioxidants, and some biochemical parameters.

\section{MATERIALS AND METHODS}

\section{Animals and Samples}

The study was performed on 15 healthy hair obtained from kid goats (control group) and 15 from kids naturally infected with Peste des Petits Ruminants (PPR) in the province of Elazig, Eastern of Anatolia, Turkey. Ages of the affected kid goats ranged from 2 and 4 month olds. The kids had a history of six days of disease. All the animals were kept under the same care and feeding conditions.

Blood samples were taken by veni puncture from the jugular vein into heparinized and nonheparinized vacutainer tubes. The nonheparinized blood samples were kept at room temperature for $2 \mathrm{~h}$ in order to obtain serum. Plasma and serum was separated by centrifugation $\left(700 \mathrm{~g}\right.$, at $\left.+4^{\circ} \mathrm{C}\right)$ and stored at $-20^{\circ} \mathrm{C}$ until analysis.

\section{Detection of PPR antibodies}

Competitive enzyme linked immunosorbent assay (C-ELISA) was used for serological detection of PPRV specific antibodies. Serum was collected from 15 clinically ill kid goats analysed for the detection of antibodies against to PPR by a commercial C-ELISA kit (PPR Competition, Competitive ELISA kit) ${ }^{1}$. The ELISA was performed according to the manufacturer's instruction as described elsewhere [2].

\section{Detection of PPR virus}

A reverse transcription polymerase chain reaction (RT-PCR) was performed for the detection of PPR virus. The tissue samples such as lymph node, spleen, lung, and oro-nasal swaps were used as RTPCR material. The reaction was carried out with a PPRV-specific primer set (PPRVF1b: AGTACAAAAGATTGCTGATCACAGT and PPRVF2d: GGGTCT CGAAGG CTAGGCCCGAATA) originally designed by Forsyth and Barrett [17] in order to amplify a 448bp cDNA product from the F gene. A lyophilized live PPR vaccine, produced by the Etlik Veterinary Control and Research Institute Ankara, Turkey, was used as the positive control. RNA was extracted from the positive 
control or tissue homogenate from the field samples using RNeasy Mini Kit, (Qiagen, RNeasy Mini Kit) ${ }^{2}$ according to manufacturer's protocol. The RT-PCR was performed with Qiagen One- Step RT-PCR kit (Qiagen, RT-PCR kit) $)^{2}$. The $20 \mu \mathrm{L}$ reaction mixture contained 7 $\mu \mathrm{L}$ Molecular Grade Water, $0.8 \mu \mathrm{L} 10$ pmol of forward and reverse primers, $4.0 \mu \mathrm{L}$ buffer, $0.8 \mu \mathrm{L}$ dNTP mix, $0.8 \mu \mathrm{L}$ enzyme mix, $4.0 \mu \mathrm{L} 5 \mathrm{x}$ Q-Solution, $2.6 \mu \mathrm{L}$ template RNA. The thermocycling profile was as follows: reverse transcription at $50^{\circ} \mathrm{C}$ for $30 \mathrm{~min}$, initial denaturation and activation of polymerase at $94^{\circ} \mathrm{C}$ for $15 \mathrm{~min}$, followed by 35 cycles of denaturation, annealing and extension at $94^{\circ} \mathrm{C}$ for $1 \mathrm{~min}, 50^{\circ} \mathrm{C}$ for $1 \mathrm{~min}$ and $72^{\circ} \mathrm{C}$ for $2 \mathrm{~min}$, respectively, and final elongation at $72^{\circ} \mathrm{C}$ for $7 \mathrm{~min}$ (Thermal Cycler) ${ }^{3}$. The RT-PCR products were analysed by electrophoresis at $80 \mathrm{~V}$ for $2 \mathrm{~h}$ on $1.5 \%$ agarose gel stained with ethidium bromide. PCR products with a molecular size of $448 \mathrm{bp}$ were considered indicative for PPRV [6].

\section{Serum Biochemistry}

Concentrations of plasma biochemical parameters were analysed by a clinical chemistry analyser (Advia 1200) ${ }^{5}$, and blood biochemical indices determined, including total protein, albumin, alkaline phosphatase (ALP), aspartate amino transferase (AST), $\gamma$-glutamyl transferase (GGT), lactate dehydrogenase (LDH), glucose, very low density lipoprotein (VLDL), low density lipoprotein (LDL), high density lipoprotein (HDL).

\section{Oxidative stress parameters}

The plasma CAT activity was measured as previously described by GOTH (20). Briefly, $0.2 \mathrm{~mL}$ of plasma samples was incubated in $1.0 \mathrm{~mL}$ substrate ( $65 \mu \mathrm{mol}$ hydrogen peroxide per $\mathrm{mL}$ of a $50 \mathrm{mM}$ phosphate buffer, $\mathrm{pH} 7.0$ ) at $37^{\circ} \mathrm{C}$ for $60 \mathrm{~s}$. The enzymatic reaction was terminated with $1.0 \mathrm{~mL}$ of a $32.4 \mathrm{mM}$ ammonium molybdate solution. Hydrogen peroxide was measured at $405 \mathrm{~nm}$ against blank containing all the components except the enzyme on a spectropho-

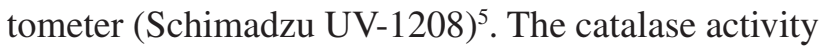
was expressed as kU/L.

The plasma GSHPx activity was determined according to the method of Lawrance [31]. The reaction mixture contained of $50 \mathrm{mM}$ of a potassium phosphate buffer (pH 7.0), $1 \mathrm{mM}$ of EDTA, $1 \mathrm{mM}$ of sodium azide ( $\mathrm{NaN} 3), 0.2 \mathrm{mM}$ of reduced nicotinamide adenine dinucleotide phosphate (NADPH), $1 \mathrm{U} / \mathrm{ml}$ of oxidized glutathione (GSSG)-reductase, $1 \mathrm{mM}$ of GSH, and $0.25 \mathrm{mM}$ of $\mathrm{H}_{2} \mathrm{O}_{2}$. Enzyme source $(0.1 \mathrm{~mL})$ was added to $0.8 \mathrm{~mL}$ of the above mixture and incubated for $5 \mathrm{~min}$ at $25^{\circ} \mathrm{C}$ before the initiation of the reaction by the addition of $0.1 \mathrm{~mL}$ of peroxide solution. The absorbance at $340 \mathrm{~nm}$ was recorded for $5 \mathrm{~min}$ on a spectrophotometer. The activity was calculated from the slope of the lines as micromoles of NADPH oxidized per minute. The blank value (the enzyme was replaced with distilled water) was subtracted from each value. The protein concentration was also measured by the method of Lowry [37]. The results were expressed as $\mathrm{U} / \mathrm{g}$ of proteins.

The plasma lipid peroxidation level was measured according to the concentration of thiobarbituric acid reactive species [42]. The amount of produced MDA was used as an index of lipid peroxidation. Briefly, one volume of the test sample and two volume of stock reagent $(15 \%, \mathrm{w} / \mathrm{v}$ trichloroacetic acid in 0.25 $\mathrm{N} \mathrm{HCl}$ and $0.375 \%$, w/v thiobarbituric acid in $0.25 \mathrm{~N}$ $\mathrm{HCl})$ were mixed in a centrifuge tube. The solution was heated for $15 \mathrm{~min}$ in boiling water. After cooling, the precipitate was removed by centrifugation at 500 $g 10$ min and then absorbance of the supernatant was measured at $532 \mathrm{~nm}$ against a blank containing all reagents except test sample on a spectrophotometer. The lipid peroxidation level was expressed as $\mu \mathrm{mol} / \mathrm{L}$.

\section{Antioxidant vitamins analysis}

Vitamin C values were colorimetrically determined using a phosphotungustic acid method described by Kyaw [30] and vitamin E values were determined spectrophotometrically according to Martinek's method [39]. All vitamin analyses were performed in the serum.

\section{Statistical analysis}

The statistical analysis was performed using SPSS Ms package program (Windows Release 10.0) ${ }^{6}$. T tests for independent samples were used for evaluating data between groups. Results were expressed as means \pm standard deviations, and $P<0.05$ was taken as the level of significance.

\section{RESULTS}

PPRV antibodies were detected by C-ELISA in all serum samples of clinically sick kid goats. PPRV was isolated and identified in RT-PCR from the tissue, such as blood samples and oro-nasal swabs collected 
from all the sick goats. Moreover we can observe the specific 448 bp band obtained from the DNA amplification of $\mathrm{F}$ protein-coding gene using the primers PPRVF1b: AGTACAAAAGATTGCTGATCACAG T and PPRVF2d:GGGTCTCGAAGG CTAGGCCCGAATA (Figure 1).

As shown in Table 1, plasma MDA concentrations were markedly increased in the group of kids with PPR $(P<0.001)$ whereas GSHPx $(P<0.01)$, and
CAT $(P<0.01)$ activities were significantly depressed as well as concentrations of vitamins $\mathrm{E}(P<0.05)$ and vitamin $\mathrm{C}(P<0.001)$.

Significant differences between groups were showed relative to plasma total protein $(P<0.05)$, albumin $(P<0.05)$, ALP $(P<0.05)$, AST $(P<0.01)$, GGT $(P<0.05)$, LDH $(P<0.05)$, glucose $(P<0.001)$, VLDL $(P<0.05)$, LDL $(\mathrm{P}<0.01)$, and HDL $(P<$ $0.05)$ [Table 2].

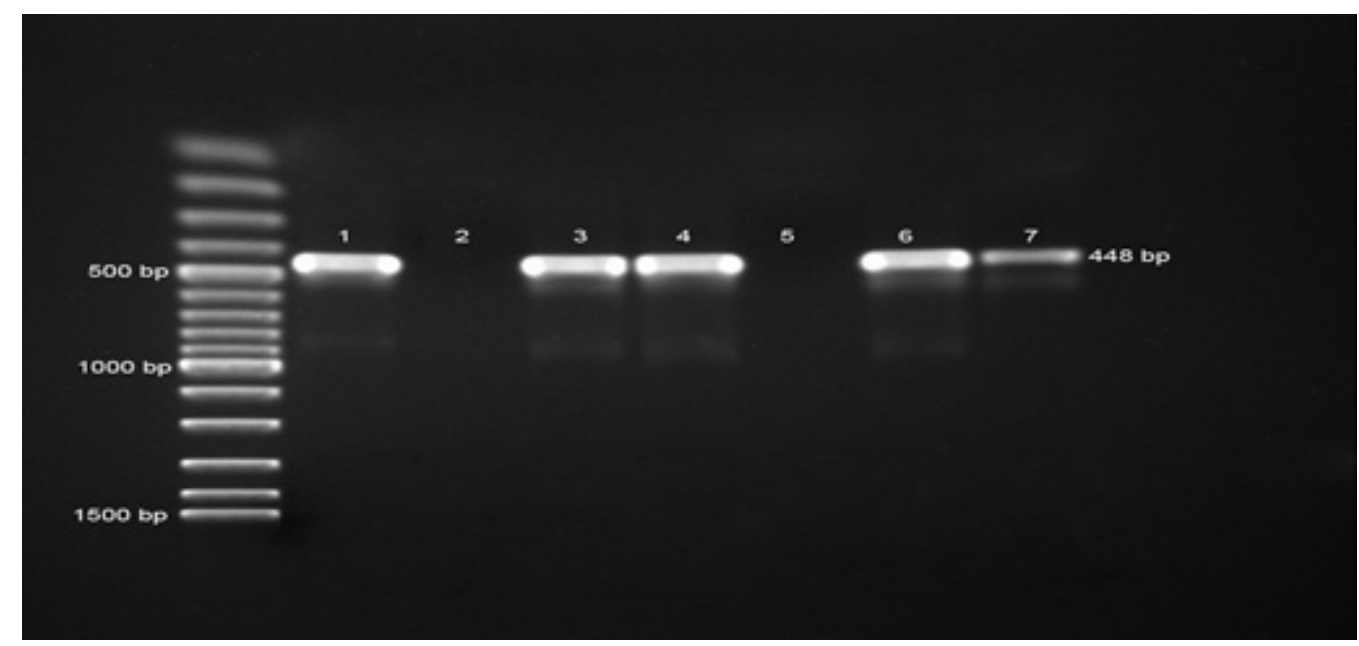

Figure 1. Agarose Gel Electrophoresis of PPRV. PCR Positive and Negative specimens and controls. Line 1- Positive control; Line 2-Negative Control; Line 3- Positive lymph node sample; Line 4- Positive lymph node sample; Line 5- Negative sample; Line 6- Positive blood sample; Line 7- Positive oro-nasal swap sample.

Table 1. Plasma oxidative stress parameters and antioxidant vitamin concentrations in kid goats naturally infected by PPR $(n=15)$ and in healthy controls $(n=15)$. Results are expressed as mean \pm standard deviation.

\begin{tabular}{|c|c|c|c|}
\hline \multirow{2}{*}{ Parameter } & \multicolumn{2}{|c|}{ Groups } & \multirow{2}{*}{$P$} \\
\hline & PPR & Healthy & \\
\hline MDA (mmol/L) & $2.00 \pm 0.39$ & $1.33 \pm 0.38$ & $* * *$ \\
\hline GSHPx (U/g protein) & $0.80 \pm 0.19$ & $1.06 \pm 0.11$ & $* *$ \\
\hline CAT (kU/L) & $22.2 \pm 6.6$ & $31.9 \pm 11.8$ & $* *$ \\
\hline Vitamin E (mg/L) & $0.86 \pm 0.11$ & $1.11 \pm 0.15$ & $*$ \\
\hline Vitamin C (mg/L) & $2.87 \pm 0.5$ & $3.92 \pm 0.4$ & $* * *$ \\
\hline
\end{tabular}

Table 2. Plasma biochemical parameters and total NEFA concentrations in kid goats naturally infected by PPR $(n=15)$ and in healthy controls $(\mathrm{n}=15)$. Results are expressed as mean \pm standard deviation.

\begin{tabular}{cccc}
\hline \multirow{2}{*}{ Parameter } & \multicolumn{2}{c}{ Groups } & \multirow{2}{*}{$P$} \\
\cline { 2 - 3 } T.protein (g/dL) & PPR & Healthy & $*$ \\
Albumin (g/dL) & $6.76 \pm 0.26$ & $3.00 \pm 0.21$ & $*$ \\
ALP (U/L) & $2.98 \pm 0.17$ & $3.19 \pm 0.23$ & $*$ \\
AST (U/L) & $63.6 \pm 9.6$ & $56.4 \pm 7.5$ & $* *$ \\
GGT (U/L) & $124.5 \pm 13.5$ & $95.5 \pm 9.2$ & $*$ \\
LDH (U/L) & $64.6 \pm 10.1$ & $53.1 \pm 3.73$ & $*$ \\
Glucose (mg/dL) & $241.1 \pm 46.5$ & $204.6 \pm 33.5$ & $* *$ \\
VLDL & $45.2 \pm 7.3$ & $66.2 \pm 6.9$ & $*$ \\
LDL & $2.13 \pm 0.5$ & $3.26 \pm 1.7$ & $*$ \\
HDL & $27.4 \pm 8.8$ & $39.0 \pm 10.2$ & $*$ \\
\hline
\end{tabular}

Data are given as means \pm standard deviation; $* P<0.05 ; * * P<0.01 ; * * * P<0.001$. 


\section{DISCUSSION}

In the Turkey, Eastern of Anatolia is one of the regions made intensive of livestock. The presence of PPRV infection in Turkey has been reported before different studies [19,41,44,52]. Although the clinical and postmortem findings may be sufficient for the diagnosis of PPR in the endemic areas, yet labaratory confirmation is essential for definitive diagnosis because of the clinical similarity of PPR to rinderpest $[34,36]$. Immunocapture [35] and reverse transcription polymerase chain reaction (RT-PCR) followed by nucleotide sequencing $[11,17,48]$ are the current diagnostic methods for all morbillivirus infections. Furthermore, due to simplicity, high sensitivity, and economy, several competitive enzyme-linked immunosorbent assays (c-ELISA) have been recognised as suitable systems for use for diagnosis and seroepidemiological surveillance $[8,9,23,24,45]$. We used both C-ELISA and RT-PCR in the diagnosis of suspected disease. We determined that the diagnostic value of necropsy materials such as lymph node, oro-nasal swap and blood were determined more valuable diagnostic materials in the diagnosis of PPRV infection by RT-PCR.

The liver is not a primary target for the PPR virus and may be fatty degenerated [26,50]. Toplu et al. [50] and Yarım et al. [51] reported multifocal areas of coagulative necrosis and vacuolation of hepatocytes and abnormal liver function test in sheep naturally infected with PPR and significant increases in mean serum concentrations of AST and ALT. In this study, small multifocal necrotic foci and haemorrhagic areas were seen as macroscopically in the liver. Capsular fibrosis, severe hidropic degeneration in the hepatocytes, multifocal necrosis foci, disorganisation in the hepatic cord, and some haemorrhagic areas were seen in the microscopic examination. Furthermore, proliferation of the bile ducts, and mononuclear cell infiltration were seen in the periportal perivascular areas. These histopatological findings were confirmed that the liver damage was formed during PPRV infection. Significant increases especially ALP, AST, and GGT, and significant decreases in total protein and albumin in the kids with PPR was consistent to the liver damage.

The liver plays a central role in the regulation of lipoprotein synthesis and degradation as well as in the storage of lipids in various lipids. Therefore, liver dysfunction can be associated with dys- or paralipo- proteinaemia [47]. In this study, the decrease level of VLDL, LDL, and HDL in the kid goats with PPR were consistent findings with liver damage, and the cause of decrease could be inadequate synthesis of cholesterol that main structure of lipoproteins due to liver dysfunction.

The glucose level was lower in the PPR group than control. The cause of the low concentration in the infected kid goats could lose of their appetite.

The determination of lipid peroxidation status (MDA concentrations) is among the most widely used methods for determination of the oxidative stress. Increased malondialdehyde (MDA) concentration in plasma is a marker of lipid peroxidation [25,39]. Lipid peroxidation is a non-enzymatic chain reaction based on oxidation of mainly unsaturated fatty acids. It leads to the creation of lipid peroxides and other intermediates. These intermediates may influence the properties of cell membranes, and one of the most common of these intermediates is MDA [10,28]. In this study, plasma MDA concentrations were found to be increased in the kids with PPR compared to the control group, while decreases of GSHPx, and CAT activities were observed. Because of GSHPx and CAT are involved in the conversion of radicals into less effective metabolites, these changes coupled to the increase of MDA concentrations, suggest that an excessive ROS production occurred during PPR infection.

Vitamin E (in the form of $\alpha$-tocopherol) is the major lipid-soluble antioxidant of lipoproteins and biomembranes [27,31,49]. Vitamin C (ascorbic acid) functions as a potent water soluble chain-breaking antioxidant in the biological fluids, but it can not scavenge the radicals within the lipid region of the membranes [16]. The synergism between ascorbic acid and $\alpha$-tocopherol in the inhibition of lipid peroxidation is well known. Vitamin $\mathrm{C}$ enhances the antioxidant activity of vitamin $\mathrm{E}$ by recycling the $\alpha$-tocopheroxyl radical back to $\alpha$-tocopherol and the depletion of the $\alpha$-tocopherol is markedly reduced $[5,20,29,37]$.

In this study, the concentrations of serum vitamin $\mathrm{E}$, and vitamin $\mathrm{C}$, which are responsible for protecting the cells from damage caused by lipid peroxidation, were found significantly lower in the PPR group than in the control group. The decrease of plasma antioxidant vitamins could results to their over utilisation due to the disease related oxidative stress. 
E. Baydar, A. Yuce, M. Gurcay \& O. Kizil. 2018. The Antioxidant Status and Biochemical Parameters in Kid Goats Naturally Infected

\section{CONCLUSION}

In conclusion, this study has highlighted the occurrence of an oxidative stress with important differences in antioxidant status as reflected by assessment of some enzymatic and non-enzymatic antioxidants in kids infected by PPRV. There is no effective therapy for PPRV infection especially young goats, and due to oxidative stress might be an aggravating factor of the disease, it can be useful to add the antioxidant vitamins such as vitamin $\mathrm{E}$ and $\mathrm{C}$, to the classical treatment procedures for get ride of the disease.
MANUFACTURERS

${ }^{1}$ IDVet Innovative Diagnostic kits. Grabels, France.

${ }^{2}$ Qiagen GmbH. Hilden, Germany.

${ }^{3}$ Techne TC-PLUS thermal cyclers. Staffordshire, UK.

${ }^{4}$ Siemens Healthcare Diagnostics Inc. Erlangen, Germany.

${ }^{5}$ Shimadzu Coorparation. Kyoto, Japan.

${ }^{6}$ SPSS Inc. Chicago, IL, USA.

Declaration of interest. The authors report no conflicts of interest. The authors alone are responsible for the content and writing of the paper.

\section{REFERENCES}

1 Al-Majali A., Hussain M.N.O., Amarin N.M. \& Majok A.A. 2008. Seroprevalance of, and risk factors for, peste des petits ruminants in sheep and goats in Northern Jordan. Preventive Veterinary Medicine. 85(1-2): 1-8.

2 Anderson J., Mccayj A. \& Butcher R.N. 1991. The use of monoclonal antibodies in competetive ELISA for the detection of antibodies to rinderpest and petse des petits ruminants viruses. In: Jeggo M.H. (Ed). The sero-monitoring of rinderpest throughout Africa-Phase one. In: The Proceedings of a final research Co-ordination meeting of the FAO/ IAEA/SIDA/OAU/IBAR/PARC Co-ordinated Research Programme (Ivory Coast. 1990). IAEA-TECDOC. 623: 43-53.

3 Banyard A.C., Parida S., Batten C., Oura C., Kwiatek O. \& Libeau G. 2010. Global distribution of peste des petits ruminants virus and prospects for improved diagnosis and control. Journal of General Virology. 91: 2885-2897.

4 Bao J., Li L., Wang Z., Barrett T., Suo L., Zhao W., Liu Y., Liu C. \& Li J. 2008. Development of one-step realtime RT-PCR assay for detection and quantitation of peste des petits ruminants virus. Journal of Virological Methods. 148(1-2): 232-236.

5 Bell A. 1995. Regulation of organic nutrient metabolism during transition from late pregnancy to early lactation. Journal of Animal Science. 73: 2804-2819.

6 Brzezinska-Slebodzinska E., Miller J.K., Quigley J.D., Moore J.R. \& Madsen F.C. 1994. Antioxidant status of dairy cows supplemented prepartum with vitamin E and selenium. Journal of Dairy Science. 77: 3087-3095.

7 Castillo C., Hernandez J., Lopez-Alonso M., Miranda M. \& Benedito J.L. 2003. Values of plasma lipid hydroperoxides and total antioxidant status in healthy dairy cows: preliminary observations. Archives Animal Breeding. 46: 227-233.

8 Choi K.S., Nah J.J., Choi C.U., Ko Y.J., Sohn H.J., Libeau G., Kang S.Y. \& Joo Y.S. 2003. Monoclonal antibodybased competitive ELISA for simultaneous detection of rinderpest virus and peste des petits ruminants virus antibodies. Veterinary Microbiology. 96: 1-16.

9 Choi K.S., Nah J.J., Ko Y.J., Kang S.Y. \& Jo N.I. 2005. Rapid competitive enzyme-linked immunosorbent assay for detection of antibodies to peste des petits ruminants virus. Clinical and Diagnostic Laboratory Immunology. 12(4): 542-547.

10 Comborti M. 1989. Three models of free radical-induced cell injury. Chemico-Biological Interactions. 72(1-2): 1-56.

11 Couacy-Hymann E., Roger F., Hurard C., Guillou J.P., Libeau G. \& Diallo A. 2002. Rapid and sensitive detection of peste des petits ruminants virusby a polymerase chain reaction assay. Journal of Virological Methods. 100: 17-25.

12 Couacy-Hymann E., Bodjo C., Danho T., Libeau G. \& Diallo A. 2007. Evaluation of the virulence of some strains of peste-des-petits-ruminantsvirus (PPRV) in experimentally infected West African dwarf goats. The Veterinary Journal. 173: $178-183$.

13 Couacy-Hymann E., Bodjo S.C., Danho T., Kofi M.Y., Libeau G. \& Diallo A. 2007. Early detection of viral excretion from experimentally infected goats with peste-des-petits ruminants virus. Preventive Veterinary Medicine. 78: 85-88.

14 Davies K.J.A. 2000. Oxidative stress, antioxidant defences, and damage removal, repair and replacement systems. International Union of Biochemistry and Molecular Biology Life. 50: 279-289. 
15 Diop M., Sarr J. \& Libeau G. 2005. Evaluation of novel diagnostic tools for peste des petits ruminants virus in naturally infected goat herds. Epidemiology \& Infection. 133: 711-717.

16 Eicher-Pruiett S.D., Morrill J.L., Blecha F., Higgins J.J., Anderson N.V. \& Reddy P.G. 1992. Neutrophil and lymphocyte response to supplementation with vitamin C and E in young calves. Journal of Dairy Science. 75: 16351642.

17 Forsyth M.A. \& Barret T. 1995. Evaluation of polymerase chain reaction for the detection and characterisation of rinderpest and peste des petits ruminants viruses for epidemiological studies. Virus Research. 39: 151-163.

18 Goth L. 1991. A simple method for determination of serum catalase activity and revision of reference range. Clinica Chimica Acta. 196: 143-152.

19 Gulyaz V. \& Ozkul A. 2005. Pathogenicity of a local peste des petits ruminants virus isolate in sheep in Turkey. Tropical Animal Health and Production. 37: 541-547.

20 Gutteridge J.M. 1993. Free radicals in disease processes: a compilation of cause and consequence. Free Radical Research Communications. 19(3): 141-158.

21 Hallivell B. \& Gutteridge J.M. 1985. The importance of free radicals and catalytic metal ions in human diseases. Molecular Aspects of Medicine. 8(2): 189-193.

22 Herdt T.H. \& Stowe H.D. 1991. Fat-soluble vitamin nutrition for dairy cattle. Veterinary Clinics of North America: Food Animal Practice. 7: 391-415.

23 Hummel K.B., Erdman D.D., Heath J. \& Bellini W.J. 1992. Baculovirus expression of the nucleoprotein gene of measles virus and utility of the recombinant protein in diagnostic enzyme immunoassays. Journal of Clinical Microbiology. 30: 2874-2880.

24 Ismail T., Ahmad S., D'souza-Ault M., Bassiri M., Saliki J., Mebus C. \& Yılma T. 1994. Cloning and expression of the nucleocapsid gene of virulent Kabete $\mathrm{O}$ strain of rinderpest virus in baculovirus: use in differential diagnosis between vaccinated and infected animals. Virology. 198: 138-147.

25 Itze L. 1984. Ascorbic acid metabolism in ruminants. In: Wegger I., Tagwerker F.J. \& Moustgaard J. (Eds). Workshop. Ascorbic Acid in Domestic Animals. Copenhagen: Royal Danish Agr Soc., pp.120-130.

26 Khan H.A., Siddique M., Arshad M., Abubakar M., Akhtar M., Arshad M.J. \& Ashraf M. 2009. Post-vaccination antibodies profile against peste des petits ruminants (PPR) virüs in sheep and goats of Punjap, Pakistan. Tropical Animal Health and Production. 41: 427-430.

27 Kleczkowski M., Klucinski W., Shaktur A. \& Sikora J. 2005. Concentration of ascorbic acid in the blood of cows affected with mastitis. Bulletin of the Veterinary Institute in Pulawy. 49: 203-207.

28 Kızıl O., Ozdemır H., Karahan M. \& Kızıl M. 2007. Oxidative stres and alterations of antioxidant status in goats naturally infected with Mycoplasma agalactia. Revue de Medecine Veterinaire. 158(6): 326-330.

29 Kohen R. \& Nyska A. 2002. Oxidation of biological systems: oxidative stres phenomena, antioxidants, redox reactions, and methods for their quantification. Toxicologic Pathology. 30: 620-650.

30 Kyaw A. 1978. A simple colorimetric method for ascorbic acid determination in blood plasma. Clinica Chimica Acta. 16: 151-157.

31 Lawrence R.A. \& Burk R.F. 1976. Glutathione peroxidase activity in selenium-deficient rat liver. Biochemical and Biophysical Research Communications. 71: 952-958.

32 Lefevre P.C. \& Diallo A. 1990. Peste des petits ruminants. Revue Scientifique Et Technique. 9: 935-981.

33 Lefevre P.C., Diallo A., Schenkel F., Hussein S. \& Staak G. 1991. Serological evidence of peste des petits ruminants in Jordan. Veterinary Record. 128: 110-111.

34 Libeau G., Diallo A., Calvez D. \& Lefevre P.C. 1992. A competitive ELISA using anti-N monoclonal antibodies for specific detection of rinderpest in cattle and small ruminants. Veterinary Microbiology. 31: 147-160.

35 Libeau G., Diallo A., Colas F. \& Guerre L. 1994. Rapid differential diagnosis of rinderpest and peste des petits ruminants using an immunocapture ELISA. Veterinary Record. 134: 300-304.

36 Libeau G., Prehaud C., Lancelot R., Colas F., Guerre L., Bishop D.H. \& Diallo A. 1995. Development of a competitive ELISA for detecting antibodies to the petse des petits ruminants virus using a recombinant nucleoprotein. Research in Veterinary Science. 58: 50-55.

37 Lowry O.H., Rosebrough N.J., Farr A.L. \& Randall R.J. 1951. Protein measurement with folin phenol reagent. The Journal of Biological Chemistry. 193: 265-275. 
38 Machlin L.J. \& Bendich A. 1987. Free radical tissue damage: protective role of antioxidant nutrients. The FASEB Journal. 1: 441-446.

39 Martinek R.G. 1964. Method for determination of vitamin E (total tocopherols) in serum. Clinical Chemistry. 10: 1078-1086.

40 Miller J.K., Brzezınska-Slebodzınska C. \& Madsen F.C. 1993. Oxidative stress, antioxidants, and animal function. Journal of Dairy Science. 76: 2812-2823.

41 Ozkul A., Akca Y., Alkan F., Barrett T., Karaoglu T., Dagalp S.B., Anderson J., Yesilbag K., Cokcaliskan C., Gencay A. \& Burgu I. 2002. Prevalence, distribution, and host range of peste des petits ruminants virus, Turkey. Emerging Infectious Diseases journal. 8: 708-712.

42 Placer A.Z., Linda L.C. \& Johnson B. 1966. Estamination of product of lipid peroxidation (Malonly Dialdehyde) in biochemical systems. Analytical Biochemistry. 16: 359-364.

43 Radostits O.M., Gay C.C., Hinchcliff K.W. \& Constable P.D. 2007. Veterinary Medicine. A textbook of the diseases of cattle, sheep, pigs, goats, and horses. 10th edn. London: Saunders Elsevier, 2065p.

44 Sahinduran S., Albay M.K., Sezer K., Ozmen O., Mamak N., Haligur M., Karakurum C. \& Yıldız R. 2012. Coagulation profile, haematological and biochemical changes in kids naturally infected with peste des petits ruminants. Tropical Animal Health and Production. 44: 453-457.

45 Saliki J.T., Libeau G., House J.A., Mebus C.A. \& Dubovi E.J. 1993. Monoclonal antibody-based blocking enzymelinked immunosorbent assay for specific detection and titration of peste-des-petits-ruminants virus antibody in caprine and ovine sera. Journal of Clinical Microbiology. 31: 1075-1082.

46 Scott G.R. 1990. Peste des petits ruminants (goat plague) virus. In: Dinter Z. \& Morein B. (Eds). Virus Infections of Vertebrates. Amsterdam: Elsevier, pp. 355-361.

47 Seidel D. 1987. Lipoproteins in liver disease. Journal of Clinical Chemistry and Clinical Biochemistry. 25: 541-551.

48 Shaila M.S., Shamaki D., Forsyth M.A., Diallo A., Kitching R.P. \& Barrett T. 1996. Geographic distribution andepidemiology of peste des petits ruminants virus. Virus Research. 43: 149-153.

49 Smith K.L., Todhunter D.A. \& Schoenberger P.S. 1985. Environmental mastitis: cause, prevalence, prevention. Journal of Dairy Science. 68: 1531-1553.

50 Toplu N. 2006. Characteristic and non-characteristic pathological findings in peste des petits ruminants (PPR) of sheep in the Ege district of Turkey. Journal of Comparative Pathology. 13: 135-141.

51 Yarım G.F., Nisbet C., Yazıcı Z. \& Gumusova S.O. 2006. Elevated serum total sialic acid concentrations in sheep with peste des petits ruminants. Medycyna Weterynaryjna. 62: 1375-1377.

52 Yesilbag K., Yılmaz Z., Golcu E. \& Ozkul A. 2005. Peste des petits ruminants outbreak in western Turkey. Veterinary Record. 157: 260-261. 